\title{
RECENT DEVELOPMENTS IN INCOME TAXATION OF THE PETROLEUM INDUSTRY
}

\author{
EDWARD J. BROWN*
}

\begin{abstract}
This paper examines recent federal budget incentives (and some dis-incentives) for the industry, recent income tax jurisprudence such as the Alberta \& Southern Gas decision, certain tax innovations in drilling and production fund corporations and partnerships, and some tax features of recent techniques used to acquire assets and shares of petroleum companies. The paper concludes with a recommendation for more generous tax treatment of drilling pre-payments and non-recourse financings.
\end{abstract}

\section{INTRODUCTION}

The purpose of this paper is to describe developments during the past year in income tax related to the oil and gas industry. Certain tax techniques currently being applied to the creation of drilling funds and the acquisition of petroleum companies will also be examined.

It should be noted that the resource taxation rules depart significantly from "generally accepted accounting principles" as adopted by the Chartered Accountants. That is probably just as well. In preparing a submission for the Independent Petroleum Association of Canada to the Alberta Securities Commission, we discovered that there are no less than five complete accounting regimes that accountants have adopted for accounting for and reporting oil and gas revenues and expenses. ${ }^{1}$

It will also be noted that the legislators have created maximum incentives to the industry through two devices. First, current expenditures and capital outlays have been blended together to some degree so that the concept of amortizing expenses of a capital nature has been blurred. Secondly, these expenses are placed in special pools so that they are written off more quickly and no amount goes into taxable income until the pool is completely depleted. The result is relatively rapid write-offs of expenditures and effective "shields" against taxation of receipts. Essentially, all exploration and development (E \& D) costs (including property acquisition costs) are deductible and the rates reflect the perceived degree of risk and the level of government encouragement.

It is generally fair to say that the Canadian tax system is more generous to the explorer than is the American tax system. ${ }^{2}$ It is submitted that this

- Solicitor, Dome Petroleum Limited., Calgary, Alberta. Valuable comments on this paper from Dome's income tax accounts are gratefully acknowledged.

1. The methods are known as "full cost" or "flow through" accounting, (the most popular use for Canadian companies), "successful efforts accounting" (stipulated by the Financial Accounting Standards Board for financial statements of U.S. companies), "reserve recognition accounting" (stipulated by the U.S. Securities and Exchange Commission for use in registration statements and reports to that Commission), "tax accounting" or "tax effect accounting" (sometimes used to show a company's after-tax position rather than establishing artificial "deferred tax reserves"), and "replacement cost accounting" or "inflation recognition accounting" (advocated by Canadian Institute of Chartered Accountants for both audit and tax purposes but not yet adopted by accountants generally or by Revenue Canada). See Dome Petroleum Limited/IPAC submission to Alberta Securities Commission on Oil \& Gas Program Guidelines, Dec. 1978.

2. Appendix A contains a comparison of Canadian and American Tax Treatment of oil and gas profits and expenses. 
system is a major contributor to the high level of exploration activity in Canada in recent years. ${ }^{3}$

Nevertheless, even greater incentives will be needed because it is estimated that the Canadian energy industry will need a third of a trillion dollars of new investment over the next ten years."

Thus, while this paper acknowledges the substantial tax incentives available to the industry, areas are identified where inequities or disincentives must be corrected if these mammoth investments are to proceed.

\section{BRIEF ANALYSIS OF 1978 FEDERAL BUDGET AND RECENT AMENDMENTS TO THE REGULATIONS}

Tax lawyers and tax accountants in the petroleum industry in 1978-79 have had extreme difficulty in advising their corporate and individual clients because of the federal government's inability to enact promised legislation and to finalize promised amendments to the regulations.

Perhaps the most dramatic case in point is the promised extension of the $100 \%$ Canadian exploration expense write-off for non-principal business corporations.

\section{A. Canadian Exploration Expense}

The general rule was that where a taxpayer was an individual or a corporation that was not a Principal Business Corporation ${ }^{5}$ (P.B.C.) the maximum amount deductible was $30 \%$ of the taxpayer's cumulative Canadian exploration expense at the end of any taxation year after May $1974 .{ }^{\circ}$ However, in 1976 a special provision was introduced allowing such non-Principal Business taxpayers to deduct Canadian Exploration Expenses incurred after May 25, 1976 and before July 1979 up to full extent (100\%) in any year. ${ }^{7}$ The attractiveness of this write-off to non-P.B.C.'s was largely responsible for the proliferation of oil and gas drilling funds and payments-to-earn-shares as tax shelters.

The federal government recognized the effectiveness of this deduction in overcoming the reluctance of individual investors to plunge into the highrisk/high capital expenditure world of petroleum investment. However, unless the provision was amended, Canadian exploration expenses incurred by such individuals after June 1979 would be deductible at only $30 \%$. Accor-

3. In 1978, a record 7170 wells were completed in Canada (including oil, gas, abandoned and suspended), for a total depth of 7,712,531 metres, an increase over 1977 of $15.7 \%$ in well completions and $20.5 \%$ in metres drilled. See Nickle Daily Oil Bulletin, May 11, 1979, 7, ascribing this information to Canadian Oil Scouts Association and Canadian Petroleum Association. In 1978, in the western sedimentary basin in the four western provinces, with an area of some 500,000 square miles, approximately 400 drilling rigs were active. The same number of rigs were active in the same period in the entire Rocky Mountain area of the United States, which is approximately double the land area and is geologically similar to the Canadian Western sedimentary basin. One might infer from this that for equivalent area, the Canadian industry was twice as active as the U.S. industry. See Dome/IPAC Submission to Alberta Securities Commission, supra n. 1.

4. Speech by R.B. Ashforth, Senior Vice-President, Royal Bank of Canada to Petroleum Society of CIM at Banff reported in Daily Oil Bulletin of May 11, 1979.

5. Income Tax Act, R.S.C. 1970, c. I-5, as am. (hereinafter referred to as "The Act"), s. 66(15)(h).

6. The Act, s. 66.1(3).

7. The Act, paragraph 66.1(3)(a)(i) 
dingly, in his November 16, 1978 Budget, the Minister of Finance proposed the following "Ways and Means Motion":"

(19) That the provisions of the Act permitting the deduction of Canadian exploration expenses incurred before July, 1979 by individuals and non-principal business corporations be extended to expenses incurred before 1982.

This was followed by the introduction of Bill C-37 to amend the Income Tax Act with a Clause 20 which would implement that extension. However, despite insistent urging by the industry and the investment community, Bill C-37 died with the dissolution of Parliament on March 26, 1979. Fortunately for the industry and resource investors "Remission Orders" were obtained under the federal Financial Administration Act $^{9}$ and equivalent orders from the governments of Alberta, Ontario and other provinces. ${ }^{10}$ These have the effect of "remitting" to individuals and non-P.B.C.'s the difference between the $100 \%$ and the $30 \%$ for C.E.E. incurred from July 1 to the end of 1979 . This is only a stop-gap and it is hoped that the government will enact new legislation to make effective the extension to 1982.

B. Supplementary Depletion

Although the new "supplementary depletion" incentives were first introduced more than a year ago in the April 10, 1978 Budget Speech, the department had not implemented it by regulation until quite recently. ${ }^{11} \mathrm{Ac}$ cordingly, it is appropriate to call it a "recent development".

The new depletion incentives are in two categories:

1. "Enriched Depletion" for "special machinery, equipment and other facilities acquired for enhanced oil recovery systems". Such expenditures earn depletion at the "enriched" rate of $\$ 1$ for $\$ 2$ of expenditure. This contrasts with the $\$ 1$ for $\$ 3$ rate under "normal" earned depletion regulations.

2. "Accelerated Depletion" of $50 \%$ of total income including resource profits for corporations involved in non-conventional oil projects with respect to depletion earned on "tertiary recovery equipment and certain depreciable property acquired for use in a bituminous sands mining project." This " $50 \%$ of all income" is a marked advantage over the limitation of "normal" earned depletion to $25 \%$ of resource profits.

There were two immediate reactions to these provisions. The first was dismay that these provisions restricted the accelerated depletion to corporations, thereby foreclosing tax sheltering possibilities for individuals. ${ }^{12}$ The government has not chosen to revise this to include individuals. The second reaction was that expressions like "facilities for enhanced recovery" and "non-conventional" oil "and tertiary recovery equipment" and "certain

8. House of Commons, Ways and Means Motion, November 16, 1978, clause 19.

9. R.S.C. 1970, c.F-10; Federal Order-in-Council dated March 29, 1979.

10. Alberta Cabinet Order-in-Council 370/79, May 1, 1979; Ontario Cabinet Order-in-Council 1324/79, May 9, 1979; B.C. Order-in-Counsel 1425, May 25, 1979; Manitoba Order-inCouncil 473, May 16, 1979; Sask. Order-in-Council EC 407/79, May 17, 1979; N.B. Orderin-Council 79/433, June 7, 1979; Nfld. Order-in-Council 79/693 dated June 1, 1979; Quebec Bill 42 presented for first reading May 31, 1979.

11. SOR/79-245.

12. A non-corporate taxpayer's deduction for both earned depletion and supplementary depletion will be limited to $25 \%$ of his resource profits, so he doesn't have an "acceleration" (i.e. he has no faster write-off than with earned depletion). 
depreciable property acquired for use in a bituminous sands recovery project" could force lawyers to engage batteries of petroleum engineers and geologists to help interpret the regulations, resulting in endless technical disputes. Fortunately, the new Regulations ${ }^{13}$ show that the draftsmen in Finance avoided the debate by adopting straight forward definitions that ignore distinctions such as "what is secondary?" "what is tertiary?".

The qualifying enhanced recovery equipment is any equipment acquired after April 10, 1978 that produces oil incremental to oil that would be recovered using the natural energy of the reservoir. ${ }^{14}$ It takes in, for example, the relatively simple pumps, injection and recovery equipment, lines and filters used in waterflooding a reservoir for conventional oil, and, on the other extreme, the complex and substantial equipment for "in situ" recovery of heavy oils and non-conventional oil deposits. In fact, both "enriched" and "accelerated" depletion are available for enhanced recovery equipment, whether it is in a conventional or a non-conventional oil area.

Tar sands mining projects are not so blessed; their expenditures earn only the "accelerated" and not the "enriched" depletion allowance. The "acceleration"15 is earned on "bituminous sands equipment", defined as assets acquired for use in a tar sands mine or an expansion of an existing tar sands mine by $25 \%$ or more of its capacity. ${ }^{16}$

The attractiveness of the supplementary depletion is evident for corporations in areas of enhanced recovery involving a high proportion of costs of tangible property, such as in steam injection processes, and undoubtedly it will boost the heavy oil and oil sands projects. However, it gives no incentive for individuals to participate in these projects at a time when it has been demonstrated that hundreds of millions of badly needed risk dollars can be attracted from that source. Also, it will be of very limited benefit to miscible flood recovery projects because it is directed only to tangible property costs which are a relatively smaller part of such programs.

\section{Depletion Recapture}

On April 27, 1978 the Minister of Finance announced a change to the Earned Depletion regulations. Previously an expenditure could "earn" depletion yet the retrieval of that expenditure (as by a sale of the property or service that first earned it), did not reduce the earned depletion base. The new provision $^{17}$ requires that where items are sold or costs recovered which previously earned depletion, the earned depletion base will be reduced by $33^{1 / 3} \%$ of the sale proceeds or amount of recovered costs. Generally the amendment to the regulation continues to exclude items that did not earn depletion in the first place. ${ }^{18}$ It is a natural parallel to the existing provisions ${ }^{19}$ that recapture

13. Part XII Income Tax Regulations S.O.R. 79-245, sections 1206 and 1213 (hereinafter referred to as "Regs.")

14. Regs., s. 1206(1)

15. Regs., s. 1213(1)(a) and (3)(b).

16. Regs., s. 1206(1).

17. Regs., 8. 1205(g).

18. It is important to keep in mind that the acquisition of Canadian resource property generates Canadian Development Expense (30\% declining balance) but no Earned Depletion. Therefore on the sale of that property, the proceeds reduce the cumulative Canadian Development Expense pool but do not reduce the Earned Depletion base.

19. The Act, s. 66(12.1). 
amounts recovered on expenses that previously generated Canadian exploration expense (CEE) or Canadian development expense (CDE) write-offs. (For example, the cost of siesmic work is added to cumulative CEE pool but sale of that siesmic results in the proceeds being deducted from the cumulative Canadian exploration expense (CCEE) pool by that provision.) However, exceptions are made in the regulations so that, if the purchaser or person reimbursing the costs (i.e. on the other side of the transaction) does not thereby earn depletion, there is no reduction of the vendor's earned depletion base. Similar provisions have been introduced to cause deductions from the "Frontier Exploration Base"20 and the "Supplementary Depletion Base".

\section{Completion and Recompletion Costs}

There has been some uncertainty in the industry as to whether completion costs of an exploratory well or a development well were to be included in the CEE or CDE pools or would be deductible as operating expenses. It would be advantageous to have CEE or CDE treatment because there would be no time limit on deduction (operating expenses can only be carried forward five years as non-capital losses) and CEE or CDE would generate Earned Depletion (and even Frontier Exploration Allowance in the case of CEE exceeding $\$ 5$ million for that well).

Another problem was that completion costs and recompletion costs did, and still do, reduce the taxpayer's income eligible for the Resource Allowance. The oil and gas industry feels that this is an inequitable situation.

The November 1978 Budget ${ }^{22}$ and Bill C-37 ${ }^{23}$ would have amended the definitions of $\mathrm{CEE}^{24}$ and $\mathrm{CDE}^{25}$ retroactively for all tax years ending after May 6, 1974 to include completion costs.

The Budget and Bill provisions cited above also would include the costs of Recompletion, that is, the work necessary to maintain or extend the useful life of a producing oil or gas well in Canada incurred after November 16, 1978. Such Recompletion costs would be included in CDE at 30\% declining balance and generate earned depletion of $\$ 1$ for $\$ 3$ of eligible expenditures.

Although it is not entirely clear, it would appear that this proposed treatment would extend to "workover" costs and costs of obtaining production from an alternative zone. At present these costs have been treated as ordinary operating expenses.

\section{E. Successor and Second Successor Corporations}

Under the present law, any unclaimed resource-related cost incurred by a "predecessor corporation" is automatically transferred to a successor corporation that acquires "substantially all" the property the predecessor used in carrying on a resource business. ${ }^{28}$ The Budget ${ }^{27}$ and the Bill ${ }^{28}$ would pro-

\footnotetext{
20. Regs., s. $1207(2)(c)$.

21. Regs., s. 1213(3)(h).

22. Income Tax Ways and Means Motion, supra n. 8, paragraph 21.

23. An Act to amend the Statute law relating to income tax, to amend the Canada Pension Plan and to provide other authority for the raising of funds, 4th Sess., 30th Parl. 1978-79, Bill C-37, clauses $20(6)$ and $21(2)(H$. of $C$.).

24. The Act, paragraph 66.1(6)(a)(ii).

25. The Act, paragraph 66.2(5)(a)(i)(B).

26. The Act, ss. 66(6), 66(7), 66.1(4), (5), 66.2(3), (4).

27. Income Tax Ways and Means Motion, supra n. 8, paragraph 23.

28. Bill C-37, supra n. 23, clauses 19(1) and (3), 20(2) and (4) and 21(1).
} 
vide that these rules would apply to property acquisitions after November 16,1978 only if both parties (predecessor and successor, or successor and second successor) so elect. ${ }^{2 \theta}$ It was further proposed that proceeds of disposition of resource properties acquired from the predecessor be deducted from the cumulative CDE pool inherited, with excess proceeds being deducted from the successor's own cumulative CDE pool.

The elective nature of the succession is desirable. It not only removes the anomaly of disposing of predecessor properties for proceeds in excess of the "notional" cumulative CDE because the successor no longer had any "predecessor" properties; it also reduces the effect of dispositions on the successor's cumulative CDE (because predecessor cumulative CDE is used up first).

\section{F. Storage Rights}

The Bill also proposed ${ }^{30}$ that, after November 16, 1978, storage rights for oil and gas would be added to the definition of "Canadian Resource Property". ${ }^{31}$ Accordingly, acquisition costs of such Rights would be added to cumulative $\mathrm{CDE}$ for an annual deduction of $30 \%$ on a declining balance basis.

\section{G. Investment Tax Credit}

The investment tax credit (I.T.C.) ${ }^{32}$ is a percentage of the capital cost of "qualified property" or qualifying expenditures in respect of scientific research made in the current year and the five immediately preceding tax years (plus I.T.C. flowing to taxpayer from his trusts or partnerships, less I.T.C. deducted, in the five immediately preceding tax years). The "qualified properties"s3 include buildings, machinery and equipment acquired by taxpayer between June 23, 1975 and July 1, 1980.

Under present law the rates of I.T.C. are $5 \%, 7 \%$ and $10 \%$ depending on expenditures for qualifying property in certain designated geographical regions in Canada. ${ }^{34}$ The credit was to expire July $1,1980$.

Under November 16, 1978 Budget $^{35}$ and Bill C-37 $7^{36}$ the July 1980 deadline would be extended indefinitely and the respective percentages for the various regions would be increased to $7 \%, 10 \%$ and $20 \%$.

\section{H. Research and Development Credit}

Under the Budget, ${ }^{37}$ the $5 \%$ basic investment tax credit rate ${ }^{38}$ would be increased to $10 \%$ for all research and development expenditures.

29. Income Tax Ways and Means Motion, supra n. 8, paragraph 26; Bill C-37, supra n. 23, subclauses 19(2) and (4), 20(3) and (5).

30. Income Tax Ways and Means Motion, supra n. 8, paragraph 24; Bill C-37; supra n. 23, subclause 19(5).

31. The Act, s. 66(15)(c).

32. The Act, s. 127(5).

33. The Act, ss. 127 (5) and (10).

34. Information circular 78-4, April 17, 1978.

35. Income Tax Ways and Means Motion, supra n. 8, paragraph 2.

36. Bill C-37, supra n. 23, clause 40(1) to (6).

37. Income Tax Ways and Means Motion, supra n. 8, paragraph 2.

38. Under the Act, SS. 37 and 37.1, 2900 and Information Circular 78-4, April 17, 1978. In Alberta, south of a horizontal line drawn through St. Paul and Whitecourt, the credit is $5 \%$; above that line, the credit is $7 \frac{1}{2} \%$. Similar North/South divisions apply for the other provinces except that the Atlantic Provinces and Gaspe qualify for $10 \%$. 


\section{CONTINUING NEED FOR REFORM}

The industry has applauded many of the tax amendments in recent regulations and contained in Bill C-37 (the future of which will be unknown until the new Conservative Finance Minister presents his budget.) However, the industry has identified a number of areas which badly need reconsideration. These may be briefly identified as follows:

1. In the enhanced recovery of conventional oil, there is a continuing failure to treat the injection medium as $\mathrm{CDE}$ and eligible to earn depletion (the new "Supplementary Depletion" only recognizes costs of "tangible property"). Present treatment of this cost as operating expense adversely impacts on the Resource Allowance.

2. Workover costs and costs of obtaining production from an alternative zone at present are treated as operating expense; they should be CDE and earn depletion. Bill C-37 would treat recompletion costs as CDE but that Bill expired and it is uncertain whether Finance regards recompletion and workovers as synonymous or even related. Also, such treatment should be retroactive to May 6, 1974.

3. When many of the tax incentives are introduced, they are given a time limit of 2 or 3 years. Since most significant projects require over 3 years from planning to implementation, these time limits should be expanded to 5 years at a minimum.

4. Frontier Exploration Allowance is scheduled to expire March 31, 1980. This incentive has stimulated activity in remote areas such as the Beaufort Sea and Eastern offshore and attracted valuable individual investment. However, there are long lead times involved in the advance technology required for frontier areas and the capital expenditure needs are massive. The March 1980 deadline is too close to allow for this lead time and mobilize the necessary capital investment. The allowance should be extended for at least 5 years.

5. As mentioned under the heading "Canadian Exploration Expense", the CEE write-off for individuals and non-principal business corporations drops at the end of June from $100 \%$ to $30 \%$ but remission orders have extended the $100 \%$ to the end of 1979 .

This incentive has drawn in the order of $1 / 2$ billion dollars of private investment capital into the industry in 1977 and 1978, and has enhanced overall Canadian investment in our industry. Therefore, it should be extended at least five years or even permanently.

6. Many complex corporate reorganizations could be avoided and there could be proper matching of revenues and expenditures for tax purposes if Revenue Canada allowed consolidated tax returns for related companies.

7. In situations such as capital cost allowance and investment tax credit, the tax act reduces the base by the amount of certain goverment grants or incentives. As a result, what is given is partially taxed. Apparently the Finance Department does this so that the incentives are on a netafter-tax basis. It would be clearer to understand and easier to calculate if the incentive was set at the net figure and was entirely nontaxable.

8. In calculating the "Resource Allowance" as $25 \%$ of "Resource Profits" the regulations require the deduction of virtually all resource related 
expenditures (even scientific research expenditures), except exploration and development expenditures and interest. This greatly reduces the resource allowance and fails to recognize that it was intended generally to offset the non-deductibility of provincial royalties. This intent would be accomplished by setting "Resource Allowance" at $25 \%$ of gross production income.

9. The present adverse treatment of non-recourse financing and drilling pre-payments has also been noted and is dealt with in detail later in this paper.

\section{1978 - 1979 INCOME TAX CASES RELATING TO OIL \& GAS INCOME TAXATION}

\section{A. The Alberta \& Southern Case}

Seldom in recent judicial history has a case been so replete with challenging questions. Thus it was rather frustrating when on November 10, 1978 the Supreme Court of Canada dismissed the Crown's appeal with the curt two sentences orally delivered by Martland, J.:39

We have not been persuaded by the arguments of counsel for the Appellant that there is error in the conclusions reached by the Federal Court of Appeal. The appeals are dismissed with costs.

While many in the petroleum industry applauded that result it was something less than a ringing endorsement of the lower court decisions and it provides little scope for analysis.

The focus of the case is the so-called "production payment", or to use the American jargon, the "carve-out". This is the right to oil and gas in place (that is, an interest in a resource property) which entitles its owner to a specified fraction of the total production from the property for a limited time or until a specified sum of money or a specified number of units of oil and gas has been received.

This has been widely used in North America for financing of exploration and development of a particular property. Party A, with the right to take production, sells an interest in that production to Party B. By making payment to $A, B$ is entitled to receive specified maximum proceeds of production if and when production is obtained. Assuming that there is no guarantee by Seller A that the specified amount will be paid to Buyer B, then Buyer B would be treated as having purchased an interest in a Canadian Resource Property. Accordingly, Buyer B would have a CDE deduction on this acquisition cost and the proceeds of production he receives would qualify as "resource profits" eligible for the "Resource Allowance" seller's part the sale price for the production payment would be deducted from his cumulative CDE account and any excess over that account's balance would be included in his income for tax purposes. ${ }^{11}$ If the production was from Crown land, then Seller A as working interest holder may be continuing to pay the Crown royalties although Buyer $B$ has the resource profits; the result is that Seller A misses the Resource Allowance that should be deductible against those profits but he has added back to his income the "phantom

39. The Queen v. Alberta \& Southern Gas Co. Ltd. 78 D.T.C. 6566, [1978]C.T.C. 780; 77 D.T.C. 5244, [1977].C.T.C. 388 (F.C.A.); (1976) C.T.C. 639 (Fed. Ct. Tr. Div.).

40. The Act, paragraph 20(1)(V.1); Regs., ss. 1204 and 1211.

41. The Act, paragraph 66.2(1). 
income" (as tax lawyers like to call it), that is, the non-deductible Crown royalty amounts. ${ }^{22}$

A variation on the arrangement involves $\mathrm{Mr}$. B. acting as a financier for operator $A$ and lending the funds to $A$ so that $A$ has a legal obligation to repay to $B$ and $A$ gives security for the loan by assigning an interest in the future production. This arrangement is a loan financing so that $\mathrm{B}$ has not acquired resource property, has no CDE acccount addition and receives the payments not as resource profits but as loan repayments part of which is taxable interest.

In the U.S., "carve-outs" became so common and the distinction between loan and property acquisition so troublesome ${ }^{43}$ that the U.S. tax law was amended to treat all such arrangements as mortgage loans. This effectively ended use of the practice. ${ }^{44}$

This was the background facing the trial and appeal divisions of the Federal Court.

Alberta \& Southern Gas Company Ltd. ("A. \& S.") acquired natural gas in Alberta and resold it to an affiliate for consumption in California. It used part of the price charged on that resale to ensure its future supplies by making prepayments for known gas in the ground and making loans to producers to assist in developing reserves dedicated to A. \&S. In this case, A.\&S. found that it had a surplus revenue of $\$ 4$ million. To avoid having the sum fall into its income for 1972 tax purposes, it entered a "carve-out" with Amoco Canada Petroleum Company Limited ("Amoco"). In consideration for the payment of $\$ 4$ million, Amoco assigned to A. \& S. a working interest in certain lands which would end when A. \& S. received production proceeds of $\$ 4$ million plus interest or a cash payment of $\$ 4$ million plus interest. A. \&S. was entitled to take the production in kind or leave it to Amoco to extract, market and pay A. \& S. its share. In fact, A. \& S. left it entirely to Amoco. Approximately one year later Amoco paid A.\&S. \$4 million plus interest thereby ending the arrangement.

The claim by A. \& S. for write-off of the $\$ 4$ million payment to Amoco was disallowed on reassessment. The issues before the trial division were:

1. Was A. \& S. a "principal business corporation" under paragraph 66(15)(h)? Was it merely acting as an agent for its U.S. parent or in its own right?

2. Was A. \& S. entitled to deduct the acquisition cost as "Canadian Exploration and Development Expense", under paragraph 66(15)(b), it being a pre-1974 expenditure? Or was it a non-deductible financing arrangement?

3. Was the A. \& S. - Amoco arrangement a "sham" device to artificially reduce income for tax purposes which the Minister could prohibit under subsection 245(1)?

4. Are the "245 avoidance provisions" available to the Minister in a resource-related context or are they overriden by the specific resource taxation provisions of sections 54,65 and 66 ?

42. The Act, paragraphs $12(1)(0)$ and $18(1)(\mathrm{m})$.

43. See, e.g. P.G. Lake v. Commissioner of Internal Revenue 58.1 U.S.T.C. paragraph 9428; 356 U.S. 260; 78 S.T.C. 691; I.R.S. Cumulative Bulletin 1958-1 C.B. 516.

44. U.S. Internal Revenue Code section 636. 
The first question was whether Alberta \& Southern was a "PrincipalBusiness Corporation" or merely an agent of its U.S. parent as the Crown alleged. Only if it were acting in its own right as a P.B.C., (a concept discussed earlier) could it claim Canadian Exploration \& Development (CE \& D) Expense deduction under the pre-1974 Act for the full amount.

After reviewing A. \& S.'s Canadian activities, Cattanach, J. focused on the word "marketing" in the definition of a P.B.C. ${ }^{45} \mathrm{He}$ concluded that A. \& S.'s business of buying and selling natural gas qualified as "marketing" and that it was not acting merely as a purchasing agent for its U.S. parent. Neither of these two points was reversed on appeal.

A second question was whether by acquiring a share of Amoco's Canadian Resource Property A. \& S. had actually acquired a Canadian Resource Property to be eligible for the CE \& D deduction, or whether it was merely acquiring title to petroleum substances existing under Amoco's lands. Even worse, was A. \& S. merely giving Amoco a one-year term loan for which there is no resource deduction?

The trial judge could find no enforceable loan obligation because the essence of a loan is that the advance shall be repaid and there was no assurance of recourse against, or repayment by, Amoco. Accordingly, he quickly rejected that assertion by the Minister. ${ }^{16}$

On the related point, the judge found no inconsistency between Amoco's transfer to A. \& S. of a right of ownership in the petroleum substances, and the grant to A. \& S., of a right to take those petroleum substances. He therefore concluded that A. \& S. had acquired in its own right a Canadian Resource Property ${ }^{47}$ the price was the full amount paid, and A. \& S. had incurred Canadian E \& D expense which entitled it to the deduction under the Act.

The next issue was whether the transaction was a "sham", that is a patently artificial device to avoid tax.

The principal example of "sham" in Canada is the decision in M.N.R. v. A.T. Leon et al. ${ }^{8}$ There, a series of agreements whose sole purpose was the saving of income tax was held to constitute a "sham". "Sham" had earlier been defined by Diplock, L.J. in the Snook case: ${ }^{10}$

It means acts done or documents executed by the parties to the 'sham' which are intended by them to give to third parties or to the Court the appearance of creating between the parties legal rights and obligations different from the actual legal rights and obligations (if any) which the parties intend to create.

Cattanach, J. considered this definition and concluded that no "sham" existed because the agreements between A. \& S. and Amoco created the exact legal rights that the parties intended to create: "If the parties to a contract do precisely what they contract to do, there is no sham"..$^{\circ}$ The Crown apparently did not appeal on this issue and it was not disputed by the Court of Appeal.

A major question was whether the Minister could attack a transaction successfully on the grounds that it led to an artificial reduction of income when

45. The Act, subparagraph 66(15)(h)(i) and (1976) C.T.C. 639 at 647-48.

46. Id., at 649 .

47. Id., at 650 .

48. Id., at 532.

49. Snook v. London \& West Riding Investments, Ltd. (1967) 1 ALL E.R. 518 at 528.

50. (1976) C.T.C. 639 at 651 and 652. 
there was a lack of a non-tax business purpose but the transaction was otherwise legally effective.

The Income Tax Act does not specifically require the existence of a non-tax motive for a deal to be allowed. However, this test may be inferred from the various anti-avoidance sections 55,67,69, 245(1) and 247(1) and (2). Australia, and to lesser extents, Great Britain and the United States, have legislative rules against so-called "no-legitimate business purpose" or "step" transactions.

Canada's two highest courts have had the opportunity to examine this issue comprehensively and lay down rules, but they have declined to take any really illuminating position. For example, in Dominion Bridge Company Limited $\mathrm{v}$. The Queen ${ }^{\mathrm{si}}$ a Canadian company interposed a subsidiary in an off-shore tax haven to supply foreign steel and thereby reduce the parent's Canadian taxes. They were scrupulous to observe all formal legal steps and documentation. The Minister alleged that there was no business purpose, only an intent to reduce taxable income artificially. The Federal Court of Appeal heard the case but made little reference to business-purpose in its judgment and decided on other grounds.

In Harris v. M.N.R. ${ }^{52}$ the Supreme Court had another opportunity to advance the understanding of the relevance of a "business-purpose" test in the context of Section 245(1)'s predecessor section. Again, the closest they came was an obiter dictum by Cartwright, J. at 505 . He began by noting 'Tf, contrary to the views I have expressed, we had accepted [a certain submission]" and concluded "the words in the subsection" (which is now 245(1)) "'a disbursement or expense made or incurred' are, in my opinion, apt to include a claim for depreciation or for capital cost allowance, and if the lease were construed as above suggested the arrangement embodied in it would furnish an example of the very sort of 'transaction or operation' at which (now section 245(1)) is aimed."

With this lack lustre history, observers hoped the suspence would end with the Alberta \& Southern case. The Minister unequivocally raised the debate with his assertion that the expenditure for the "carve-out", would artifically reduce Alberta \& Southern's income.

Mr. Justice Cattanach in the Trial Court found as fact that the principal officers of the Plaintiff ${ }^{\text {ss }}$ "candidly admitted that the motive of the Plaintiff for entering into these carve-out agreements with Amoco was to remove" (the $\$ 4000$ amounts) "which would have been taxable as income ... from the grasp of the tax collector to preserve these amounts... and to use these moneys at some future time ...". However, both the Trial and Appeal Courts rejected the application of s.245(1) and upheld the taxpayer's claim. In effect they concluded that, even if the taxpayer was influenced by tax considerations, in enacting the "resource incentive" provisions Parliament must have intended that a taxpayer should take full advantage of them. Thus, this could not be disallowed as an artificial reduction of income under subsection 245(1). The only difference between the Trial and Appeal Court was that the

51. Dominion Bridge Company Limited v. The Queen (1977) C.T.C. 554; 77 D.T.C. 5367.

52. (1966) S.C.R. 489, 66 D.T.C. 5189.

53. (1976) C.T.C. 639 at 650.

54. See conclusion of Jackett C.J., (1977) C.T.C. 388 at 397. 
Trial judge took the position that 245(1) was completely overriden by the resource sections 66 and others. ${ }^{55}$

Section 66 and the sections immediately following dealing with exploration and development expenses of principal-business corporations quoted above are special sections and clearly express a particular intention of Parliament. On the other hand, Section 245 is a general section and expresses a general intention. In the present appeals the Plaintiff has brought itself precisely within the particular legislative intent expressed in the particular section 66 . The general intention expressed in section 245 is incompatible with the particular intention expressed in section 66 from which it follows that section 66 must govern and not section 245 .

The Court of Appeal declined to follow such a sweeping exclusion of $\mathrm{S}$. 245.Jackett C.J. observed:: ${ }^{\text {s }}$

In my view, considering it in its context in the scheme of the Act, subsection 245(1) is applicable to every class of deductible expenses. Even if, reading the Act as a whole, I came to a different conclusion, I should feel constrained to hold that subsection 245(1) does apply to deductions such as those otherwise permitted by section 66 ....

Unfortunately the Court of Appeal and Supreme Court declined to address the "business purpose" point directly and therefore its relevance in tax planning continues as an open question. The most that can be concluded is that the production payment and its kinfolk the overriding royalty and the net profits interest are acceptable as Canadian Development Expense items and should not be regarded by the Courts as financing devices. On the negative side, it also must be concluded that section $\mathrm{s}$. 245 remains alive for scrutiny of all resource arrangement and so it continues to be the "poltergeist" of the tax planner.

B. Some Minor Cases

(1) Wardean Drilling Case ${ }^{57}$

This case bears on the concepts of "Principal Business Corporation" and "Successor Corporation" discussed earlier.

The Plaintiff, Wardean, had been making exploration and development expenditures with respect to petroleum, natural gas and the search for minerals from 1951 to 1967. In 1964 (some four years before the earliest of the two tax years litigated), it sold the only "well" it owned, and it was questioned whether "Wardean" could still be considered to operate what the Courts called a "gas business".

The issue was whether that single transaction in 1964, the sale of the only well, amounted to a sale of "all or substantially all" of the assets. If so, the "successor corporation" rules would operate to flow all the E \& D deductions with the property to the new owner of the well. Thus, Wardean would not be entitled to use those $\mathrm{E} \& \mathrm{D}$ deductions against future income in years (1978 and 1979) when it could use them.

The two levels of courts found that Wardean's principal business at the sale date in 1964 was a "gas business" and not a "mining business." Accordingly, this 1964 sale represented substantially all the property used in that "gas business" so that the deductions flowed out with it.

55. (1976) C.T.C. 639 at 652.

56. (1977) C.T.C. 388 at 396.

57. Wardean Drilling Co. Limited v. Minister of National Revenue (1978) 78 D.T.C. 6202; (1978) C.T.C.270 (Fed. C.A.). 


\section{(2) Ethyl Corporation Case ${ }^{58}$}

Ethyl Corp. produced anti-knock compound at its Ontario plant for sale to refineries where it was combined with gasoline for use as engine fuel. Sales of these anti-knock products represented over $85 \%$ of Ethyl's revenues. In order to claim certain resource - related deductions, Ethyl asserted that its principal business was the production and marketing of "petroleum products" within the meaning of paragraph 83A(3)(a) of the pre-1972 Act. The Minister contended that the production of anti-knock compounds was not the production of a "petroleum product".

83A(3)(a) did not pass intact into the new Act, although subsection 66(2) does recognize certain "special product corporations". However, the expression "petroleum products" reemerged as one of the types of business ${ }^{50}$ that qualifies a company as a Principal - Business Corporation with the tax advantages it enjoys (as discussed supra).

After a detailed review of evidence by chemical engineers, the trial judge concluded that:

(a) a "petroleum product" must be a "product derived from petroleum";

(b) the question is to what extent can the petroleum be altered or processed with other components added or subtracted before it ceases to be regarded as a product of the original petroleum;

(c) as a result of the addition of substances foreign to petroleum and the extensive chemical processes applied to the various elements, the finished "anti-knock" is nota "petroleum product" within the statute.

(3) B P Petroles Case Co $^{60}$

BP operates many gas stations throughout Canada. It incurred expenses in defending itself against court applications by competitors seeking to prohibit it from operating one of its gas stations. The Minister disallowed these expense deductions on the grounds they were non-deductible capital outlays and $B$ P appealed. The Trial Division upheld the Minister, stating that these expenses were laid out to protect a capital asset - the gas station affected and thus were capital expenditures non-deductible under paragraph 18(1)(b).

\section{TAX INNOVATIONS IN PUBLIC FUNDS FOR DRILLING AND PRODUCTION}

Many companies, especially the smaller purely exploration companies, may not be in a taxpaying position. Hence, any additional tax deductions generated by the companies performing the exploration work themselves will not result in any reduction in their taxes payable until some time in the future. After considering the present value of the future tax deductions, it may not be economical for the company to accept the risk associated with the exploration program. However, an investor who has sufficient taxable income to currently use the tax deductions generated and who also is in a higher marginal tax bracket, may view the risk associated with the exploration program as acceptable. Therefore, it is in the best interest of the company to dilute its interest in the relevant properties in order to have the investors perform the exploration work.

58. Ethyl Corporation of Canada Limited v. Her Majesty The Queen (1979) 79 D.T.C. 5012; (1979) 1 A.C.W.S. 131 (Fed. Ct. Tr. Div.).

59. The Act, paragraph 66(15)(h)(i).

60. B.P. Petroles Limitee v. Her Majesty The Queen (1979) 79 D.T.C. 5121. 


\section{A. Limited Partnership Investment}

An individual, corporation or partnership can choose to make its exploration or development expenditure through a partnership. As long as that investor remains a partner at the end of that partnership's fiscal year, the tax benefits will flow out to the investor ${ }^{61}$ Limited partnerships using this device are the most common form of individual investment in the petroleum industry.

The investor can participate in this exploration work through either a limited partnership or a corporate structure.

The limited partnership concept grants limited liability protection to the individual investor and permits the operator to deal with one party (the general partner) who represents all the investors, rather than dealing with each individually. However, this alternative does not give the investor a readily marketable asset. There is almost no organized market for limited partnership units at the present time, but there have been initiatives toward eventually being able to list them on stock exchanges.

\section{B. Corporation Investment}

The alternative is the corporate structure, which has not yet received wide spread use. The Canadian Income Tax Act allows the deduction of Canadian Exploration Expense incurred as consideration for receiving shares in a company. ${ }^{62}$ This is the mechanism featured in Rangeco Oil and Gas Limited, Beaufort Exploration Limited (and its siblings) and Canshore Exploration Ltd. In these offerings, the investor made certain exploration or development expenditures and in return received preferred shares of the respective companies. In addition to receiving the preferred shares, the investor paid a nominal amount, which was not deductible for tax purposes, in order to acquire common shares. The arrangement gave the investor shares which could be listed on an exchange and became readily marketable. This liquidity feature is often lacking in other forms of tax shelters, such as MURBS, films and limited partnerships. From the operator's point of view he is largely indifferent regarding the use of either a limited partnership or a corporate format.

Using the limited partnership structure or the corporate structure, the investor obtains the write-offs for Canadian Exploration Expense, Canadian Development Expense, Earned Depletion (and for well costs over $\$ 5$ million, Frontier Exploration Allowance). While the investor can deduct CEE, CDE and FEA from any source of income, the Earned Depletion deduction is available only against resource income. Where a limited partnership is used, resource profits returned by the investment flow through to the partner and he can use his earned depletion to shield them. However, where a corporate structure is used, the resource income generated by the investment will flow into the corporation and will ultimately be returned to the investor as divi-

61. The Act, paragraphs 66.1(6)(a)(iv) and 66.2(5)(a)(iv), Regs., paragraph 1207(5)(b). The Act simply says that a taxpayer may deduct his share of CEE or CDE of a partnership if he was a member at the end of the fiscal period. This has been interpreted by a number of Revenue Canada rulings to the effect that taxpayers who are partners at the end of the fiscal year derive the tax benefits of all the CEE and CDE incurred by the partnership; however, care should be taken in drafting proper allocation clauses in the partnership agreement to achieve this result.

62. The Act, paragraph 66.1(a)(vi). 
dend income. Thus his investment will never provide him with the type of income from which he can deduct the Earned Depletion generated by his investment. Also, the corporate alternative inherently double taxes the income generated by the investment. The income is taxed once in the corporation and again when it is passed on to the shareholder in the form of dividends. Because of the restricted deductibility of the Earned Depletion and the inherent double taxation, the industry's use of the corporate alternative has been limited and the partnership structure has been much more prevalent in the drilling fund offerings to date.

The explanation for the use of corporate structure in the Beaufort and Canshore offerings was that it was not possible to obtain an unqualified legal opinion as to the law applicable to the Beaufort Sea and Eastern Offshore areas. It is uncertain whether they are in Canadian provincial waters and what jurisdiction could register a limited partnership. Without such assurance, only a corporation could assure that the partners enjoy limited liability: any partnership might not be limited and therefore would impose joint liability for the high risks in that environment. This hazard outweights any value to be given to the difference in treatment between resource income and dividend. The income, in whatever form it is received, is far enough into the future that its value is heavily discounted and its ability to absorb earned depletion is almost completely discounted. Even the investor without independent resource income still has a $167 \%$ deduction in the first year from this investment, its primary attraction to him.

The Rangeco offering was the first major drilling fund to utilize the corporate format and, at the time of its issuance, was hailed as a model that other drilling funds would follow. It basically provided the investor with two types of shares. The Rangeco preferred shares were designed primarily to give the investor his tax write-offs; the growth and value of the company were reflected directly in the value of the common share. These comon shares could be listed on a stock exchange and would be relatively easily marketed. The same mechanism is used in the "Beaufort" and "Canshore" corporations except that the "Beauforts" are unique in giving the investor an option to retract after five years and be reimbursed his approximate net-after-tax investment. In addition, the investors in Rangeco received a royalty interest. The income from this royalty interest provided the investor with a source of resource income from which could be deducted the earned depletion generated from the investment.

The nature of the interest beneficially received by the investors will dictate certain tax consequences. For example, if an investor receives a Net Profits Interest, or an overriding royalty, he usually will not pay any Crown royalties while still receiving the benefit of the "Resource Allowance"ss deduction in calculating his income for tax purposes. However, if he receives a working interest he will be making Crown royalty payments which are nondeductible for tax purposes ${ }^{64}$ but he will be eligible to claim "Resource Allowance" and to receive certain rebates of provincial income tax from B.C., Alberta, and Saskatchewan. ${ }^{65}$ In most situations, the operator of the drilling

63. Deduction from resource income of $25 \%$ of that resource income (excluding resource property sales proceeds) after deducting operating costs and capital cost allowance: The Act, paragraph 20(1)XV.1) and Regs., ss. 1204 and 1211.

64. The Act, paragraph $12(1)(0)$ and $18(1)(\mathrm{m})$.

65. Alberta Income Tax Act, R.S.A. 1970, c. 182, as am., ss. 8.4 \& 8.5; Income Tax Act, S.B.C. 1962, c. 27 as am., s. 5C; Income Tax Act, R.S.S. 1978, c.I-2, s.5A. 
fund does not want to be responsible for making the non-deductible Crown royalty payments of the investors, so the investors usually receive a working interest and are responsible for their respective proportion of the Crown royalty payments. In the Beaufort and Canshore offerings where federal Crown royalties are relevant, a net profits interest (NPI) concept was used because of the large capital expenditures contemplated in order to produce oil and gas from the area. By using this concept, the investors would not be liable for these further capital costs, as they would have been if they received a direct working interest. But in calculating their entitlement to the NPI, capital costs are taken into account. However, the investor's company, Beaufort or Canshore, was still made responsible for the investor's share of Crown royalties through a reimbursement mechanism which is contemplated by section 80.2 of the Income Tax Act. So in this situation, even though the investor's company did not receive a working interest, the onerous Crown royalty obligation was still passed on by the operator to the exploration corporation.

An important feature in analysing offerings involving Alberta lands is the Small Explorer's Tax Credit..$^{66}$

In Alberta the Province credits to each taxpayer an amount equal to $25 \%$ of the non-deductible Crown payments made to the Province, up to a maximum of $\$ 1,000,000$ per taxpayer or group of associated taxpayers. It is normally applied to reduce the taxes payable. But where the payor of the royalties has insufficient Alberta taxes payable, he receives the difference in cash on filing his Alberta Return. In certain situations, operators have already received the maximum of one million dollars and are ineligible to receive any further benefit from this plan; it costs the operator nothing to structure the deal so that the investors reap the benefits.

With respect to the Small Explorer's Tax Credit, it is very important to the investor that the production income and related Crown royalties flow through directly to him. Only with the Limited Partnership type of structure or the joint venture alternative is this flow through of production income and Crown royalty payments possible. Under the corporate structure utilized by the Rangeco offering, the production income is retained in the subject company owned by the investors with the result that the investors will collectively be subject to the one million dollar maximum.

If the operator performing the administration duties charges a flat fee, or a fee based on the actual administration costs incurred, the profit element, if any, would be taxed without any deduction permitted for Resource Allowance. However, if the fee charged is based on production from the subject resource properties, it appears that a Resource Allowance on the profit element would be permitted. The downside to this alternative is that recovery of the administration costs rests solely on the success of the exploration program. It is simply a matter of incurring more risk in return for gaining a small tax benefit.

One of the alternatives that many drilling funds have provided is for the limited partner to withdraw or retire from the partnership. For each unit he holds, the retiring partner will receive money from the partnership equal to his proportion of the value of the assets minus liabilities in the partnership.

66. Alberta Income Tax Act, R.S.A. 1970, c. 182, as am., s. 8.5. 
For example, if the oil and gas properties in the partnership have a value of $\$ 2,000,000$, the partnership has no debt, and there are one thousand partnership units, a retiring partner with one unit would receive $\$ 2,000$. The method used to calculate the value of the property in the partnership varies with and is unique to each partnership. The problem the partnership has is where to look to obtain funds to enable it to pay for the retiring units. In most cases it looks to the operator. An agreement is usually made for the operator to purchase a certain portion of the partnership's resource property assets to enable the partnership to retire any units for which a request has been made for retirement. To the operator the cost of acquiring the resource property of the partnership is treated as CDE. This is an acceptable method for the operator in that he obtains tax recognition for his cost of providing some form of limited marketibility to the limited partners. This technique was used in both the DEB Canadian Exploration 1977 and 1978 offerings.

A second alternative that has not received as wide a usage is for the operator to directly purchase the partnership units from the limited partners who requested withdrawal. The actual amount paid for each unit is again dependant on the value placed on the resource properties in the partnership. The advantage of this alternative rests with the limited partners. It is the present favoured opinion that the limited partners will receive capital gain or capital loss tax treatment, as the case may be, on the sale of their partnership interest. This is in contrast to the previous alternative where it is believed that the proceeds from the retirement of the partnership units would be effectively taxed as ordinary income. However, the disadvantage of this alternative rests with the operator. For his purposes, the acquisition of the partnership interests is treated as an acquisition of a capital property with no deduction being allowed. If the partnership ultimately is liquidated, the operator would be able to treat one-half of his adjusted cost base in the partnership interest as CDE. The Wainoco offerings use this alternative, but it has not received widespread usage, probably because of the limited tax value to the operator.

The third alternative involves the exchange of units in the limited partnership for public shares of the operator. To date, this alternative has only been used in the Lochiel Exploration offering. Under s. 85 of the Canadian Income Tax Act, where a person exchanges an asset for shares in a Canadian company, the person and the company may jointly elect for tax purposes to deem the selling and purchase price to be any amount within certain limits. For example, it would be possible to elect to have the selling and purchase price to be equal to the adjusted cost base (ACB) of the partnership unit to the partner, which is presumably how the Lochiel offering would work. If the elected amount equalled the ACB of the partnership unit, then it would be a tax free transaction to the limited partner. The investor receives a marketable security in a tax free transaction. When the investor ultimately sells the security, he will be eligible for capital gains or capital loss treatment, as the case may be. From the point of view of the operator, this alternative is less desirable. The operator will treat that elected amount as the adjusted cost base of the partnership interest received. This ACB is not deductible to him, except in the case of liquidation of the partnership, as previously mentioned. The value of any shares he issues to the investor, in excess of the elected amount, receives no tax recognition whatsoever. Also, many companies would be reluctant to issue common shares to the public in such a situation. Many 
operators would feel their shares are presently undervalued on the stock exchanges and would be unwilling to issue such shares for the current market price. In order to issue such shares the operator would demand such a high premium on issuance that most investors would probably be unwilling to part with their partnership interests.

\section{TAX FEATURES OF RECENT TECHNIQUES USED TO ACQUIRE ASSETS \\ AND SHARES OF PETROLEUM COMPANIES}

The business pages of our local and national newspapers have brought almost daily word of small, medium and even large petroleum companies being gobbled up by their ravenous neighbours. The depressed stock prices of the past years in relation to the underlying asset values made their shares too tantalizing to aggressive entrepeneurs.

Two additional factors were:

(1) the fortuitous disappearance of the "Designated Surplus" rules of the Income Tax Act which had required that, if an existing company had a "surplus" on its books, any company that acquired that company could not extract that surplus without first paying a punative $25 \%$ tax thereon to the Government;

(2) the introduction of "successor and second successor corporation" rules (67) which permit a company ("successor") acquiring "substantially all the assets" of (9nother company ("predecessor") to use all tax pools of the predecessor to shield tax on income from predecessor's resource properties.

A few of the more significant considerations leading to an acquisition and some of the more imaginative techniques employed are outlined briefly below. ${ }^{68}$

\section{A. Asset Purchase}

Income tax is at the heart of the structure of most acquisitions. For the prospective purchaser the key to the purchase price for assets is the after-tax discounted cash flow from those assets. Also, he is interested in "inheriting" the Vendor's unused deductions if he acquires "substantially all" the Vendor's resource-related assets so that he can shield future income from those properties as discussed above. But the Vendor wants to reduce the income taxes he will pay on the disposition. The focus then is on using the Vendor's tax pools to shield those disposition proceeds or to use instalment purchase methods to extend the purchase over a number of the Vendor's tax years to allow him to use reserves or develop tax shields as insulation from tax.

One method of instalment purchase that has gained legitimacy because of the Alberta \& Southern case, discussed supra is the production payment. Instead of purchasing the resource properties outright, the Purchaser may acquire a "carved-out" production payment. This gives him most of the resource profits and passes to him the "Resource Allowance" ${ }^{\text {"60 }}$ deduction, but leaves the residual working interest with the Vendor.

67. The Act, ss. 66.1(4), (5), 66.2(3).

68. A detailed analysis of this subject may be found in D. Ward, "Arm's Length Acquisitions Relating to Shares in a Public Corporation", Canadian Tax FoundationCorporate Management Tax Foundation Conference 1978, and in the papers on takeovers and reorganizations presented at the Canadian Tax Foundation Conference, Nov. 20.22, 1978.

69. The Act, paragraph 20(1)(V.1). 
Instead of cash, the Vendor might sell the Resource Assets in consideration for shares in the Purchaser Company. If the purchaser company has previously carried on a resource business, a tax-free rollover of the tax cost of the assets into the corporation under section 85(1) may not be available. However, if the purchaser company (or a subsidiary spun off by the purchaser to acquire the assets and give the'shares) has not previously carried on a resource business and qualifies as a joint exploration corporation (JEC), ${ }^{70}$ the transfer of assets and take-back of shares can be accomplished under subsection 66(10.2).

\section{B. Share Purchase}

It may be that the Vendor has no significant tax shields to protect him from tax liability on an asset sale. He may prefer the lower capital gains tax treatment if he sells the shares of the corporation that holds the resource assets. There also may be instances where an asset sale might trigger third party first refusal rights so that the assets could be lost, whereas a share sale creates no such third party problems. Another angle is to use the transfer to a JEC to have desirable assets transferred from vendor corporation $A$ to a new corporation $B$ and to sell to purchaser the shares of corporation $B$ thereby giving him exactly the assets he wants and circumventing most first refusal clauses. subsection 85(1) and Revenue Canada ruling TR-41 facilitate this. The Purchaser has no CDE write-off on the acquisition of shares as he would on assets and so the share-route is $30 \%$ to $40 \%$ less attractive to him if he is in a taxable position. Therefore, he is likely to reduce his price by that percentage. However, the purchase of shares is no real impediment to his effective use of the assets. If both purchaser company and acquired company are Canadian companies, once the Purchaser wholly owns the new subsidiary it can use subsection 88(1) to wind-up the subsidiary and absorb the assets taxfree, along with the predecessor tax pools.

The Vendor may prefer to sell his shares for shares of the Purchaser (particularly redeemable preferred shares which he could pledge with a bank and thereby realize his price as a loan the debt service on which is covered by dividends on the new shares). This share for share exchange can be tax-free if the rules in section 85.1 are followed.

Perhaps it is difficult to make the subsidiary "wholly-owned" (and thereby permit the tax-free wind-up under 88(1) ) because the shareholder cannot extract the shares voluntarily from minority shareholders. A number of devices have been concocted by resourceful entrepreneurs and their legal advisers to answer this problem.

The first device is the take-over: ${ }^{71}$ if $90 \%$ or more of the shares are presented by shareholders in answer to a public offering, a court order can be obtained to acquire the remaining $10 \%$. However, this procedure is complex, may place the offeror in a position of taking up shares after 35 days when he cannot ascertain if he has the magic $90 \%$, and is open to attack and even upset by dissenting shareholders.

A second method is the "arrangement". Under The Alberta Companies Act, $^{72}$ (and corresponding provisions for some other provinces) a company

70. The Act, paragraphs 66(15)(g), 66(10), (10.1). (10.2); Regs., 1207(5)(a).

71. Canada Corporations Act, R.S.C. 1970, c. C-32, as am., Part XVI, Companies Act, R.S.A. 1970 , c. 60 , as am., s. 153.

72. The Act, s8. 154 and 155. 
may present to its shareholders an "arrangement" to reorganize its capital. This could include an exchange of the shares for other shares or for cash. Such a resolution requires prior court approval and then must be passed by votes of a majority of shareholders representing $75 \%$ or more of outstanding shares. Such a resolution is virtually impossible for a dissenting shareholder to upset.

In an "arrangement" situation, the offeror approaches the company with a proposal to give shareholders cash or other securities for their shares. The management of the company then initiates and carries through the arrangement. Obviously this method will not work if management is hostile or suspicious. Since different shareholders have different tax situations, the third-party purchaser may offer cash so that the shareholder has a taxable capital gain equal to one half of the excess of cash offered over the adjusted cost base of the shares. A shareholder with a high 1971 V-day value in the shares could face little or no tax by this route. Or the company may offer to exchange the shares for a redeemable share. This should be a taxfree exchange under $S .86$, if the arrangement qualifies as a reorganization. Then the company would redeem that share for cash. This redemption will be a deemed dividend under S. 84. Dividends paid to Canadian corporations are tax-free under subsection 12(i)(j) and S. 112. Accordingly, a Canadian corporation would prefer the redemption route. Since most companies have both individual and corporate shareholders, a choice of either cash or exchange-redemption may be offered.

This is the method used in two recent acquisitions - Voyageur Petroleums by $\mathrm{Nu}$-West Development and Siebens Oil \& Gas by Canpar Oil \& Gas.

A third and very controversial method is the amalgamation-squeeze out. For example, corporation A has a large corporate shareholder B holding 200 shares and a minority collectively holding 50 shares. B creates a corporation " $C$ " and uses its $80 \%$ shareholding in " $A$ " to pass a resolution for an amalgamation of " $A$ " with " $C$ ", a component of this being the exchange of 100 " $\mathrm{A}$ " shares for 1 " $\mathrm{AC}$ " share. In the result, $\mathrm{B}$ holds 2 shares of " $\mathrm{AC}$ " and the former minority only hold fractional shares (i.e. $50=1 / 2$ ). Most Companies Acts allow a company to redeem fractional shares so the minority fractional shares are redeemed and the minority has been "squeezed out". The amalgamation should be tax-free under subsection 87(1). The share for share exchange should be tax-free under $\mathrm{S}$. 85.1 but the redemption will be a deemed dividend, taxable for an individual shareholder, and tax-free for a Canadian corporate shareholder.

This third method is workable in theory but Canadian courts may intervene to protect the minority.

If an offeror simply wished to offer a large amount of cash to shareholders, the Income Tax Act previously made the financing relatively inexpensive. An "Income Debenture" provided that payments of interest were made only out of profits (S. 15). Accordingly, the payments were treated as dividends and so were tax-free to a Canadian corporate lender. Also, term preferred shares which operate similarly to a term loan have payments which are treated as dividends. Since interest on a conventional loan is fully taxable while "dividends" on an income debenture or term preferred share were taxfree to a corporate lender, the lender could charge only about $52 \%$ of the interest rate and yet receive $100 \%$ of that interest rate after tax.

As a result, every financial vice-president in the oil industry knew of these 
provisions and many took advantage of them for inexpensive financing of acquisitions. The most publicized example was Petro Canada's use of such taxfree financing with a consortium of Canadian banks in its acquisition of Pacific Petroleums.

These financing methods could have spurred many acquisitions of Canadian branches of U.S. oil companies by Canadian companies and have promoted "repatriation" of the petroleum industry. However, the Finance Department has attempted to close this door by Budget item 73 and Bill C-37 clauses 65(5) and (6). These would have treated as taxable interest all payments on income debentures entered after November 16, 1978 and payments to financial institutions on term preferred shares issued after November 16, 1978.

There are variations on the asset and shares techniques where a U.S. vendor is involved but they are directed mainly to his U.S. tax situation which is beyond the scope of this paper.

\section{DRILLING PREPAYMENTS}

One area that is receiving close scrutiny from Revenue Canada is the drilling prepayment. ${ }^{73}$

The drilling prepayment is a payment by a company or partnership to an operator or contractor for drilling that will be performed in the following year or the following tax period. This can be desirable in oil and gas funds because investors tend to make their investments during the last months of the tax year when they are most conscious of the need for tax sheltering. However, the operator may not then have rigs available or have access to the drill-site; or there simply may be a need to provide the contractor with cash in advance to proceed with the work.

One method is for the contractor to offer the operator or fund manager a "turnkey" basis of contract whereby the payment is fixed no matter how much the drilling actually costs or how long it takes. Alternatively, a "cost plus" may be utilized, where the cost is fixed but extra time or expenses to the contractor bring a higher payment. In either event, all or most of the payment is made to the contractor before drilling in fact commences.

It appears that the Internal Revenue Service of the United States has accepted such drilling prepayment practices and allowed current deduction of such costs by "cash basis" (usually individuals) taxpayers where there is a business purpose for the prepayment. ${ }^{74}$

In Canada, the opposite seems to be the rule. Revenue Canada has viewed many types of prepayments with skepticism; such prepaid expenses include prepaid rentals, prepaid insurance premiums and prepayments for inventory. Thus, when the drilling prepayment appeared, the tax auditors approached it with the same caution.

This reluctance is somewhat surprising because corporations and limited partnerships in the oil industry (or any other industry) must report their income and costs on an "accrual" basis. In other words, the time reference is not to when the payment of cash is actually made but to when the cost is incur-

73. Unpublished remarks of James Walker, Calgary District Office of Revenue Canada to a luncheon of the Canadian Petroleum Tax Society, January, 1979.

74. I.R.S. Revenue Rulings 71-252 and 71-579 and M. Carten, "Federal Income Taxation of Oil and Gas Operations", (1977) 15 Alta. L. Rev. 455. 
red. That cost will have been incurred when a legally enforceable obligation to pay first comes into existence. ${ }^{75}$ Accordingly, it can be argued that as soon as the corporation or partnership executed the contract to have a well drilled and that contract stipulated that payment was required in December, there was an "expense incurred"76 at the December date, even though the contractor was not required to commence the actual drilling until the next January or later.

Nevertheless, Revenue Canada's present administrative practice appears to be that the actual drilling must have been commenced for an expense to be incurred in drilling an oil or gas well, and only the costs of that drilling to the end of the tax year can be deducted for that tax year; a mere payment or agreement to pay without evidence of drilling will not satisfy them. They appear to base their position on a literal reading of subparagraph 66.1(6)(a)(ii):

66.1(6)(a) "Canadian Exploration Expense" of a taxpayer means any outlay or expense made or incurred, or deemed to have been made or incurred, after May 6, 1974 that is. . .

(ii) any expense incurred in drilling an oil or gas well in Canada. . .

(A) incurred by him in the year,...

The recurrence of the expression "expense incurred" no less than three times in the excerpt quoted would seem to support the advocates of the "accrual basis" argument advanced previously. However, Revenue Canada appears to link "expense incurred" with "in drilling" and "in the year" to buttress its position that the drilling (and not just the obligation to pay or the actual payment) must occur in the year for which the CEE deduction is claimed.

Revenue Canada appears to make a secondary argument that if payment has been made but no drilling has occurred, then either

(a) the payment was made to an agent of the payor so that it really has not left the payor's control and therefore has not yet been "incurred" nor is it an "outlay made" (to use the introductory words of 66.1(6)(a)), or

(b) the payment was only an advance on account of costs to be "incurred" in the following year.

It can be inferred that Revenue Canada is following an unarticulated policy to squelch any potential for abuse of the prepayment by year end tax planners.

75. Revenue Canada Interpretation Bulletins do not define when an expense is incurred for exploration expense purposes but they do deal with the converse - when a receipt is receivable into income. It is submitted that the same logic applies. In IT-125R the timing of receivability is defined as follows:

An amount becomes receivable at the point in time where a collectible right to the amounts is acquired. . . he must have a clearly legal, though not necessarily immediate right to receive it.

Conversely, to claim an expense deduction the taxpayer must have a "clearly legal" obligation to pay.

The character and timing of expense for purposes of the general section 18(1) are considered in IT 109:

In order that an expense which is unpaid at the end of a taxation year may be deductible for tax purposes, the liability so created in respect of that expense must constitute a genuine liability of the taxpayer. If such an unpaid amount does not constitute a genuine liability, no deduction is allowed. In order for a genuine liability to exist, there must be an enforceable claim by the creditor with a reasonable expectation that the debt will in fact be paid by the debtor.

76. This interpretation of "expense incurred" is supported by Pickle Crow Gold Mines v. M.N.R. (1954) C.T.C. 390; 55 DTC 1001. 
Isubmit that Revenue Canada should reverse its position on the grounds of both legal interpretation and national tax policy objectives.

The phrase in the Act "expense incurred in drilling. . . incurred by him in the year" does not necessarily mean that the drilling must occur during that year. Rather, the phrase "in drilling" is a modifier as to the type of expense. It is the "expense" that is "incurred in the year", it is not drilling "performed in the year." If the intention of Parliament was to match the deduction to performance of drilling in the year, they would have used precise words and not the general word "incurred".

If the tax authorities really think that a prepayment transaction is a device to artificially reduce income at year end, then they may use subsection $245(1)$ to scrutinize resource transactions (the Court of Appeal in Alberta \& Southern confirmed that the subsection can be invoked to challenge artifical resource transactions). On the other hand, if the prepayment is legitimate and a true liability has arisen and been discharged by payment, the authorities should not interfere with a convenient and sometimes necessary business practice in the petroleum industry. If exploration and development of Canada's reserves is to be encouraged, then the government should be wary of placing impediments in the path of enthusiastic individual and corporate investment in drilling.

\section{NON-RECOURSE FINANCING}

In a paper presented to the Canadian Tax Foundation in November 1978 the Director General of Corporate Rulings for Revenue Canada, Mr. Robertson, made the following statement at 10 and 11 :

Interpretation Bulletin IT-164 issued in June 1974 . . . deals specifically with investments in films and leveraged equipment leases, but does, in fact, represent our general view that the capital cost of depreciable property or the amount of otherwise deductible expenditures (for example, exploration and development expenses) cannot include that portion in respect of which there is no legal recourse against the investor in the event of default.

While there is little jurisprudence dealing with this non-recourse concept, the Federal Court has found that the capital cost of a film investment shall not include the portion represented by liabilities payable only out of revenue, if any, generated by the exploitation of a film (Mandel v. The Queen, 76 DTC 6316 and S. McKee v. The Queen, 77 DTC 5345).

The Department has consistently insisted on full recourse financing with one notable exception, that being with real property investments in Alberta. There the governing legislation (The Judicature Act) makes it, for all intents and purposes, impossible for the mortgagor to give a personal guarantee or covenant with respect to any deficiency that may arise. Accordingly, as long as the fair market value of the collateral property exceeds at all times the outstanding liability, we have accepted the nonrecourse feature. As a matter of equity and consistency, we have extended this exception to all MURB investments, regardless of the province.

As is natural, some practitioners have pressed us to accept non-recourse financing in other areas. We have no intention of doing so at this time. We currently are studying the matter in depth with a view to isolating the tax policy matters and obtaining the views of the Department of Finance. Until the study is complete and decisions taken on the tax policy question, our present position will remain in force.

It is understood that this study by Revenue Canada, Rulings, is actively underway and that an Interpretation Bulletin on the matter may be issued by September 1979 .

While it is hoped that the study will produce enlightenment, certain objections to Revenue Canada's present position can be stated:

1. Even if an investor does not give his personal guarantee for the debt, if he is placing his property (i.e. the property in which he is investing) as security so that it is lost to him in the event of default, then in a very real economic sense he is "at risk" and the lender's legal recourse is, effective- 
ly, "against the investor".

In practice, a Canadian Bank will lend on s. 82 Bank Act security over producing petroleum reserves in place or in storage; and as long as projected cash flows more than cover debt service they will not require personal guarantees of the investors. If the banks consider that the collateral security value exceeds the outstanding liability, why should Revenue Canada dispute it? Such forms of "leverage" make an oil and gas fund attractive to investors and it is in the national interest to encourage such investment in oil and gas projects.

2. Notwithstanding Mr. Robertson's point about the Alberta Judiciature Act, ${ }^{77}$ there is no logical reason to permit non-recourse financing for one type of tax shelter (MURBs) ${ }^{78}$ while denying it for another type of tax shelter (petroleum exploration and development.)

3. The Mandel and McKee decisions dealt with particular facts on capital cost allowance claims in relation to a certain structure of film partnership, and cannot be extended to claims for Canadian Exploration or Canadian Development Expense deductions in a different industry using difference investment vehicles.

4. As the courts have stated in cases as diverse as Birmingham v. Barnes, ${ }^{79}$ Ottawa Valley Power v. M.N.R. ${ }^{80}$ and Canadian Pacific v. The Queen ${ }^{81}$ a taxpayer's "cost" for tax purposes is the amount he laid out, or incurred a liability for, and the source of that amount (where and how he obtained it) is not relevant.

5. There exists a disturbing persistent rumour that Revenue Canada, Rulings, considers that the interposition of a limited partnership between the investor and the bank operates to limit the investor's liability to the bank and therefore may constitute it a non-resource financing. The dilemma is that a general partnership cannot be used for three reasons:

(i) the limitation of liability (offered by a limited partnership) is needed to protect individual investors from the high, and not fully insurable, third-party liability risks in petroleum exploration and development;

(ii) the nature of a general partnership is to make each partner "jointly" liable for the full amount of the liabilities and financing debts of the partnership and not just for their "several" share;

(iii) section 7 of the Alberta Companies Act ${ }^{82}$ prevents a group of more than 20 persons from constituting a partnership; they must incorporate. But this would "lock" the desired tax writeoffs in the corporation and constitute income from it as taxable dividends rather than "resource profits" eligible for resource

77. R.S.A. 1970 , c. 193 , as am.

78. Multiple Use Residential Building.

79. Birmingham v. Barnes (1935) 19 T.C. 195 (H.L.).

80. Ottawa Valley Power Company v.M.N.R. (1969) 2 Ex. C.R. 64.

81. Canadian Pacific Limited v. The Queen (1976) 2 F.C. 566 (Fed. Ct. Tr. Div.), varied by the Federal Court of Appeal on a different ground (1978) 2 F.C. 439.

82. R.S.A. 1970 , c. 60 , as am. 
allowance deductions. The Limited Partnership Rules of the Alberta Partnership Act ${ }^{33}$ contain an exception to the Companies Act rule so that any number can join a limited partnership. This is essential because few drilling funds could reach even their minimum subscription with only 20 partners.

\section{CONCLUSION}

If it is the intention of the federal and provincial governments to assure Canadians self sufficiency in oil and gas or at least to insulate them from arbitrary actions by foreign countries producing those commodities, and if the policy is to achieve this through private industry, then tax incentives which will inject cash flow in to the industry and will lure in cautious private investors are essential.

At the present time the tax system lacks the efficiency to accomplish this.

Budgets are presented but are not implemented before Parliament is prorogued.

The Remission Orders given cover too short a period to be effective (the Orders extend Canadian exploration expense for a non-principal business corporation only to the end of 1979; legislation is needed to extend it at least until 1982.)

Where changes to Regulations are promised, over a year elapses before they are promulgated. When incentives finally are introduced, they are far too short-term (the aforementioned CEE was to expire July 1, 1979, Frontier Exploration Expense is to expire April 1, 1980). Yet these projects have long lead times and need assurance of a much longer regime. It should be remembered that the North Sea play took hundreds of wells and at least ten years to reach a commercial level. Why should our tax laws expect success and viability within three years?

What government gives with one hand it retrieves with the other. For example investment tax credit is available but it reduces capital cost allowances. The income debentures and term preferred shares which were so effective in reducing the cost of borrowing for many petroleum companies would be withdrawn as tax effective instruments by Bill C-37.

A positive reform would be the structuring of an investment tax credit so that it behaved like the small explorer's credit in Alberta; it would not reduce capital cost allowance base, and, if the investing company had insufficient tax payable, it would receive the credit in cash to reinvest.

Even when incentives are implemented and the courts confirm them, as occurred in Alberta \& Southern, rulings officers in Revenue Canada reserve the right to decline to rule; or Revenue Canada auditors may yet reassess because they feel the tax payer is taking advantage of the law to avoid tax. This creates a serious problem where one is developing a public offering. Officials are not legally obliged to grant advance rulings, but the Securities Commissions whose approval for public offering is required will not give that approval without an advance tax ruling.

The drilling prepayment and non-recourse financing would be valuable features in a public offering as discussed earlier, but they face a hostile reaction from Revenue Canada. 
It is submitted that this inability of government to implement its policies and these arbitrary positions by Revenue Canada Rulings officers and assessors are frustrating the will of Parliament and the interpretations of the courts, and are inhibiting the growth of resource investments at the time when Canada vitally needs them.

This paper was prepared prior to the May 22 election and it may be unfair to lay these criticisms at the door of the new administration. It is hoped that they will identify these problem areas and introduce reforms at an early date. 


\section{APPENDIX A}

\section{TAXATION BY CANADA AND UNITED STATES OF OIL AND GAS INVESTMENTS}

(SOURCE: Dome Petroleum/Independent Petroleum Association of Canada Submission to Alberta Securities Commission, December 1978)

The significant provisions of both countries with respect to oil and gas investments in each country are compared below.

1. Property Costs

a) Costs to acquire properties:

U.S.A. - All costs associated with the acquisition of property (i.e. lease bonus) are capitalized and either amortized over the life of the property if productive or deducted as an operation loss in the year of abandonment.

Canada - All such costs are capitalized and are amortized as incurred at $30 \%$ declining balance irrespective if there is production or no production in the year. Cost of abandoned leases cannot be expensed in the year of abandonment but are continued to be amortized at the $30 \%$ rate.

b) Geological and Geophysical Costs:

U.S.A. - These costs are capitalized as part of the cost of the property and amortized as acquisition costs above. If no property is acquired or retained, the costs are deducted as an operation loss when the property is abandoned.

Canada - Geological and geophysical costs are capitalized as Canadian exploration expense (CEE). CEE is deducted up to the amount of income from any source in the year. The productive potential of the property associated with G \& G costs has no bearing on the amount of deduction permitted.

2. Intangible Drilling and Development Costs

U.S.A. - A taxpayer may elect (once) either to capitalize or expense intangible drilling and development costs (IDC). If a tax payer elects to capitalize these costs, he is permitted a second election to expense IDC of non-productive wells. The election to expense IDC is made by the taxpayer in the first year he incurs IDC and is binding thereafter. If he fails to make the election at that time, he is deemed to have elected to capitalize all IDC incurred in the first and future years. Capitalized costs are amortized over the life of the productive property involved or deducted as a loss in the year the property is abandoned.

In addition to the above general principles, U.S. tax treatment capitalizes certain intangible drilling costs elected to be expensed by the taxpayer. This capitalization applies in two significant circumstances.

1. If the taxpayer pays a disproportionate share of drilling costs compared to his working interest in the property (say 
$100 \%$ of costs in earning a $50 \%$ working interest), then the excess of drilling costs he paid over his share of the working interest must be capitalized as property acquisition.

2 . If the taxpayer by paying certain drilling costs earns an interest in the property and an additional interest in other property outside the drilling property, then he must value the outside interest, and include its value in his income for tax purposes.

Another significant point to keep in mind is that in the U.S. IDC cannot be elected to be expensed unless the taxpayer incurring the driliing costs has a working or operating interest in the property. A working interest or operating interest is defined generally as an interest that has the burden of developing and operating the property.

Canada - Intangible drilling costs are classified into two types of expenditures, Canadian development expense or Canadian exploration expense. Drilling costs incurred in drilling a productive well that will come on production within 12 months after completion or is not a first commercially productive well in a previously unknown area or zone are classified as Canadian development expense and amortized at a $30 \%$ declining balance rate. The taxpayer may deduct any amount from nil to $30 \%$ in a year.

Drilling costs incurred in drilling a productive well that it is reasonable to expect will come on production within 12 months or a first well as discussed above are classified as "Canadian Exploration Expense". As noted earlier, CEE is deducted up to amount of income of any source for the year. This $100 \%$ deduction as it is commonly referred to is available to resource corporations, and as well to nonresource oriented corporations and to individuals but only for such costs incurred prior to December 31, 1981.

\section{Tangible Equipment Costs}

U.S.A. - Cost of equipment must be capitalized and depreciated. Normally the unit of production method is used to depreciate oil and gas well improvements. This method resembles cost depletion basis used in amortizing property costs.

Canada - Cost of equipment is capitalized and depreciated generally at a $30 \%$ declining balance rate (Class 10 ).

4. Other Deductions

a) Depletion

U.S.A. - Two types of depletion are provided by U.S. tax laws. Cost depletion is the amortization of capitalized costs, acquisition, geological and geophysical, intangible drilling and development (if capitalized costs) over the life of the property involved. Total cost depletion cannot exceed the costs incurred. Percentage depletion, based on production in the year (not capitalized costs) and available in very limited circumstances, permits total depletion deductions in excess of 
capitalized costs if the production life of the property still remains.

Canada - In addition to a write-off similar to cost depletion, being Canadian development expense, exploration and development expenses capitalized, with exception of cost of properties, earn an additional deduction (a non-cash outlay) referred to as an earned depletion allowance. One dollar of an earned depletion allowance becomes available for each three dollars incurred on qualifying capitalized expenditures. Earned depletion allowance is deductibile up to twenty-five percent of net profit from Canadian oil or gas production, royalty income and proceeds from sale of oil \& gas proper. ties less amounts of Canadian development expense, Canadian exploration expense and resource allowance claimed in the year. Unclaimed earned depletion, remaining due to above $25 \%$ deduction rule, may be carried forward indefinitely.

b) Frontier Exploration Allowance

Canada - In addition to earned depletion, frontier exploration allowance is earned on Canadian exploration expenses in excess of $\$ 5$ million incurred on a well. This allowance is earned at the rate of 66 cents on each dollar of CEE costs incurred in excess $\$ 5$ million per well as long as the CEE costs for a well are incurred between April 1, 1977 and March 31, 1980. This allowance is deductible against any source of otherwise taxable income up to the amount of such income for the year.

c) Resource Allowance

Canada - Canadian tax laws permit the deduction of an allowance, that is a non-cash outlay as well and is not based on cash outlays, equal to $25 \%$ of net profit from production, royalty income and non-deductible Crown payments but before deductions for Canadian development expense, Canadian exploration expense, earned depletion allowance and interest.

5. Production and Royalty Income

Both countries tax the net profit after deduction of operating expenses and the respective deductions discussed above.

6. Proceeds from Disposal of Oil and Gas Property and Tangible Property

U.S.A. - Disposition of oil and gas property may be subject to recapture of intangible drilling and development costs as ordinary income. Disposition of tangible property is subject to recapture as ordinary income of past depreciation to the extent of gain realized. Amounts of such gains are not taxed as ordinary income (above) but are taxed as a capital gain.

Canada - Total proceeds from disposition of oil and gas property is taxed as ordinary income although the timing of its taxation may be deferred since the proceeds first reduce the unclaim- 
ed CDE pool. Proceeds from sale of depreciable assets are taxed as ordinary income in amount of depreciation previously taken, and the balance, if any, is taxed as a capital gain.

\section{Investment Tax Credit}

Both countries provide an investment tax credit, deductible from the taxes payable, on qualified depreciable investment. The U.S. earning rate is $10 \%$ whereas Canadain rate proposed under the November $16,1978 \mathrm{Federal}$ Budget will vary from 7 to $20 \%$ depending on location of the qualifying assets.

\section{Royalty Payments to Governments}

Both countries have royalties payable to the respective federal or lesser level governments in specific circumstances. U.S. government royalties are deductible in computing income. In Canada, Crown royalties are not deductible in computing taxable income. As relief for the additional taxes that arise by the non-allowance of Crown royalties, the Canadian Federal government has provided the resource allowance discussed earlier. Furthermore, the oil and gas active provinces provide further relief by rebating provincial taxes on royalties disallowed less resource allowance claimed. Alberta provides a further rebate by refunding federal taxes paid on Alberta royalties (before resource allowance). This rebate is limited to $\$ 1$ million in a year for an individual or an affiliated corporate group. 